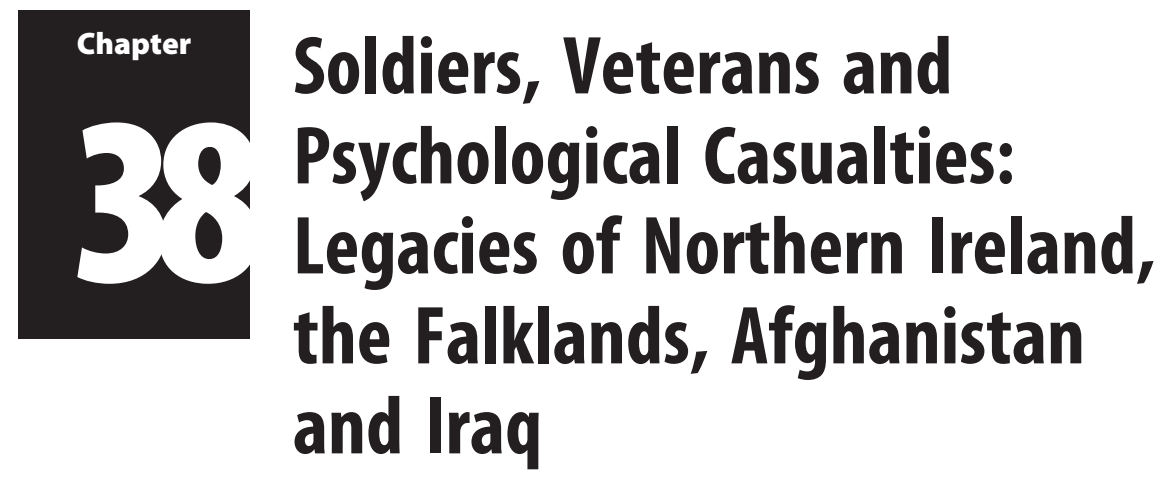

Edgar Jones

\title{
Introduction
}

While the fifty years from 1960 did not produce a conflict on the scale of the two world wars, the UK adopted an increasingly interventionist foreign policy that drew British forces into campaigns beyond Europe. Counter-insurgency operations in Northern Ireland served as an enduring backdrop, involving 300,000 UK service personnel and resulting in 1,441 deaths between 1969 and 2006. ${ }^{1}$ However, until the breakup of the Soviet Union in December 1991, the primary role of the British armed forces remained within NATO, protecting Western Europe from the Eastern Bloc. These long-term commitments were eclipsed when international destabilisation led to the breakup of Yugoslavia and UN peacekeeping roles followed in Bosnia, Kosovo and Macedonia. Yet, by 1997, after a decade of Conservative cuts, the defence budget as a percentage of GDP had shrunk to its lowest level in the twentieth century. ${ }^{2}$ In July 1998, a strategic defence review conducted by New Labour identified growing risks: terrorism in particular but also drugs, ethnic and population pressures and scarce resources. ${ }^{3}$ The government sought to create a tri-service force able to operate regularly beyond Europe on a joint and multinational basis. Designed to raise Britain's international influence, it required the military 'to punch above its weight'. ${ }^{4}$ Deployments to Sierra Leone, Afghanistan and Iraq followed, stretching the resources of the UK armed forces to the limit. The physical and psychological casualties that were sustained created a popular support for the individual soldier but eventually eroded public support for the interventionist policy.

\section{The Falklands War}

Despite the physical challenges of the terrain and the extended supply chain, the Falklands War of spring 1982 appeared to produce little post-traumatic illness, reported as 2 per cent of all wounded. ${ }^{5}$ Of the 9,000 ground troops deployed, 150 (1.7 per cent) were killed in action. Although sixteen psychiatric cases were evacuated to SS Uganda, the hospital ship, only four were diagnosed with 'battleshock', the term then used for acute stress reaction. ${ }^{6}$ The lengthy sea voyages to and from the South Atlantic were thought to have provided time to prepare mentally for combat and to readjust to peacetime soldiering or a return to civilian life. ${ }^{7}$ Research conducted after the war identified functional somatic presentations that 
elevated the rate of psychiatric casualties to 8 per cent. ${ }^{8}$ This was significantly below the 20 per cent commonly recorded for major battles in the Second World War and was explained by the short duration of the war and the fact that British troops were highly trained regulars. ${ }^{9}$

Yet subsequent studies raised the possibility that the 8 per cent of all wounded did not capture the full impact of the traumatic experience. ${ }^{10}$ In 1987, Jones and Lovett reported three delayed cases of post-traumatic stress disorder (PTSD) from members of the task force. ${ }^{11}$ Five years after the conflict, O'Brien and Hughes compared a group of sixty-four infantry soldiers who had served in the Falklands with matched controls who had equivalent training but had remained in the UK during the conflict. ${ }^{12}$ On the basis of self-report questionnaires, it was found that fourteen (22 per cent) met the criteria for PTSD and a further eighteen (28 per cent) had a range of these symptoms. PTSD scores were not associated with age, rank or length of service but were higher for those who had lost comrades through wounding or death or who had killed the enemy or assisted in the management of casualties. They were also likely to have experienced emotional difficulties on returning home from the war. In 1993, a study of Falklands' veterans found a 60 per cent rate of PTSD from fifty-three respondents who had completed a postal questionnaire. However, this was not a representative sample, as the investigators had sought volunteers using a networking model. ${ }^{13}$ While the operational success of the Falklands War was unquestioned, it increasingly appeared that the cost in terms of psychiatric casualties was hidden. In 2002, this notion received support from an article published in the Daily Mail claiming that 264 Falklands veterans had committed suicide, more than the 237 killed in the conflict. ${ }^{14}$ Research published by Defence Analytical Services and Advice in 2013 showed that 95 veterans had taken their own lives, which represented 7 per cent of the 1,335 who had then died since serving in the Falklands campaign. ${ }^{15}$ A lasting effect of the war was a change to the policy for commemoration of casualties. Following pressure from relatives, the Ministry of Defence (MoD) agreed that bodies could be repatriated to the UK for burial, ${ }^{16}$ a ritual that was to influence public opinion once campaigns in Iraq and Afghanistan proved costly.

\section{Forward Psychiatry}

Forward psychiatry, the classic method of managing breakdown on the battlefield developed during the First World War, was not employed in the Falklands. The two Navy psychiatrists with the task force remained on hospital ships throughout the campaign, so that a key element, return to unit, was prohibited under the terms of the Geneva Convention. ${ }^{17}$ Known by the acronym PIE (proximity to the battlefield, immediacy of delivery and expectation of recovery), the procedure had been widely used in the Second World War and Korea when it returned around 30 per cent of those treated to duty. ${ }^{18}$ However, the counter-insurgency operations in Malaya, which engaged British troops from June 1948 to July 1960, offered no obvious application for an intervention that required defined battle lines. As army psychiatrists with first-hand knowledge of forward psychiatry retired, training in its use ceased during the 1960s. The end of National Service saw the number of soldiers in the army fall from 430,000 in the mid-1950s (of whom just over half were conscripts) ${ }^{19}$ to 157,000 by $1965 .^{20}$ It was assumed that volunteers who had joined to the armed forces as a career would be less vulnerable to breakdown.

Forward psychiatry was reintroduced in the early 1980s in response to the threat of a massed Soviet assault from the East. ${ }^{21}$ Warsaw Pact forces had developed a tactic of 
concentrated bombardment to induce severe dissociation in front-line troops. Large numbers of 'battleshock' cases were predicted, requiring rapid treatment. ${ }^{22}$ The surprise attack on the Israeli Defense Force in the Yom Kippur War was identified as a model for an invasion of Europe, and Israeli clinicians were invited to the UK to brief their British counterparts. ${ }^{23}$ Mobile field psychiatric teams (FPTs) were formed at brigade level and attached to field ambulances, comprising two doctors and four mental health nurses, and incorporated within battlefield training. To overcome stigma and present the policy in terms that fighting units would recognise, Brigadier Peter Abraham published on 'battleshock' and briefed British troops stationed in Germany. ${ }^{24}$

\section{Northern Ireland}

Running from 1969 to 2006, counter-insurgency operations in Northern Ireland served as an enduring commitment and saw more than 300,000 UK service personnel deployed with 1,441 deaths. ${ }^{25}$ The decade from 1971 to 1980 , which saw the worst of the violence, raised the strength of troops in the province to 20,000. It was a period during which 330 regular soldiers and 107 members of the Ulster Defence Regiment were killed and many more injured. Nevertheless, combat stress reactions remained at a low level and were managed by community psychiatric nurses ( 1 per 5,000 soldiers) supported by regular clinical sessions from uniformed psychiatrists. Not until the 1980s was a full-time, army psychiatrist deployed to Northern Ireland. ${ }^{26}$ However, a study in 2015 of veterans treated for PTSD at the inpatient facility of the mental health charity Combat Stress showed that 55 per cent had served in Northern Ireland compared with the Falklands (16 per cent), Iraq (33 per cent) and Afghanistan (17 per cent). ${ }^{27}$ The preponderance was probably a consequence of the numbers deployed rather than a heightened incidence of traumatic events during the Troubles.

\section{UK Recognition of PTSD}

Although the American Psychiatric Association (APA) recognised PTSD in 1980, the association with Vietnam veterans delayed its acceptance in Britain. The 1986 edition of the Oxford Textbook of Psychiatry, for example, referred only to a 'post-traumatic syndrome' which related to 'chronic neuroses after head injury'. ${ }^{28}$ Until the 1990s, little was published on PTSD affecting UK armed forces or civilians exposed to terrorism. However, in the late 1980s, Morgan O'Connell, a Navy psychiatrist, saw an increasing number of Falklands' veterans with chronic psychological symptoms and explored the usefulness of PTSD as a diagnosis and route to treatment. On 21 December 1988, the detonation of a terrorist bomb on board Pan Am Flight 103 from London to New York introduced Royal Air Force clinicians to the new disorder. ${ }^{29}$ The aircraft crashed at Lockerbie, killing 259 passengers and crew, together with 11 local residents. Four RAF mountain rescue teams were sent to the site to look for possible survivors but found only the dead and body parts. ${ }^{30}$ Gordon Turnbull, a RAF neuropsychiatrist, employed critical incident stress debriefing (CISD) to treat the teams who had not expected to encounter such devastation. ${ }^{31}$ CISD was adopted by the military as a way of dealing with the acute effects of trauma and subsequently proposed as a way of reducing the incidence of PTSD. ${ }^{32}$ RAF psychiatrists developed a twelve-day structured, inpatient course of group psychotherapy and day case follow-up sessions, in which psychological debriefing was the main therapeutic technique. ${ }^{33}$ 


\section{Gulf War}

In contrast to the Falklands, where the size of the battlegroup was determined by available sea transport, the Gulf War in 1990-1 saw a force of 53,400 sent to Kuwait. ${ }^{34}$ With such numbers and the possibility of an extended land campaign, forward psychiatry had an obvious role. Two FPTs worked in conjunction with a Battleshock Recovery Unit. ${ }^{35}$ However, a short campaign with only forty-eight deaths resulted in few psychological casualties. The most challenging health effect emerged after the conflict and was given the popular term Gulf War syndrome. Veterans in the UK and the United States succumbed to a range of common, medically unexplained symptoms that impaired their daily function. Intense media and public interest followed in part because the mystery illness was hypothesised as having a toxic cause, whether from chemical weapons, vaccinations, organophosphates, depleted uranium munitions or oil well fires. Although a major research programme failed to find a unique disease, ${ }^{36}$ similarities were identified with post-combat syndromes from earlier wars. ${ }^{37}$ Such was the dominance of Gulf War syndrome that no studies were conducted into rates of PTSD suffered by UK service personnel and veterans until the new millennium. ${ }^{38}$ An investigation of troops deployed on peacekeeping duties between 1991 and 2000 found a PTSD prevalence rate of 3.6 per cent, ${ }^{39}$ while a study carried out from 2001 to 2002 of a representative sample of UK armed forces found a probable PTSD prevalence of only 2.5 per cent. ${ }^{40}$ These percentages were equivalent to those for the UK population as a whole (males between the ages of sixteen and sixty-four having a rate of 3.6 per cent) ${ }^{41}$ and appeared to show a military with robust mental health. In retrospect, it is surprising that the first studies of PTSD in the UK military were conducted more than twenty years after the disorder had been recognised in DSM-III. This omission was to prove costly to the MoD because it created an opportunity for a legal case brought by veterans who had served in Northern Ireland, the Falklands, the Gulf and Bosnia for negligence in the detection and treatment of PTSD. With little or no published data on rates and outcomes, they were granted legal aid to test the validity of their claim for compensation in the Royal Courts of Justice.

\section{Peacekeeping in Bosnia}

In October 1992, British troops were deployed to Bosnia as part of the UN peacekeeping operation and remained there for more than a decade. Although casualties were low, many encountered the results of atrocities or found themselves constrained by rules of engagement when presented with ethnic conflicts. A self-report study of 4,250 UK troops deployed to Bosnia between 1991 and 1997 found that they were at greater risk of heavy drinking than those who had served in the Gulf War or those who had been serving at the time but not deployed to either theatre. ${ }^{42}$ In part explained by their younger age, it was also attributed to exposure to dangerous, provoking or humiliating experiences with limited opportunities to express the resulting anger and frustration.

\section{Class Action for PTSD}

Amid much publicity, the class action brought by 2,000 UK veterans against the MoD came to court on 4 March 2002. With so much evidence to consider, it was not until May 2003 that Mr Justice Owen delivered his judgement. The landmark case, probably the most important public inquiry into the treatment of post-traumatic illness since the 
Southborough committee of inquiry into shell shock, explored six key areas: the state of knowledge, screening for vulnerability, treatment, forward psychiatry, detection together with military culture and stigma. ${ }^{43}$ Although the MoD was not found negligent, the judge identified a need to monitor developments in screening, detection and treatment. The MoD was reminded of the need to incorporate new knowledge into training, policy and practice. ${ }^{44}$ Compared with the United States and Israel, the UK armed forces had limited research capacity in military psychiatry, a function both of size and of institutional culture. Following the case, the MoD funded a major research programme at the Institute of Psychiatry and the King's Centre for Military Health Research (KCMHR) was set up in 2004, subsuming the Gulf War Illnesses Unit that had opened in 1996.

\section{Treatment}

The validation of cognitive behavioural therapy (CBT) for PTSD was the significant innovation in treatment during the period. However, the randomised controlled trials conducted in the early 1990s were of victims of sexual assault. ${ }^{45}$ With large numbers of Vietnam veterans diagnosed with PTSD, US clinicians researched new treatments during the $1980 \mathrm{~s},{ }^{46}$ though the first UK study of trauma-focused CBT for service personnel was not published until 1995. ${ }^{47}$ While it was subsequently shown that cognitive processing therapy and prolonged exposure therapy for PTSD in military and veteran populations achieved meaningful symptom reduction, 60 per cent to 72 per cent of subjects continued to meet the criteria for PTSD after treatment. Further, non-response and drop-out rates were high, suggesting a need for better ways of engaging with veterans. ${ }^{48}$

\section{Afghanistan and Iraq}

The campaigns in Afghanistan and Iraq did not produce a syndrome characterised by medically unexplained symptoms akin to that associated with the Gulf War. As a result, the main research focus was on PTSD and latterly on rates of common mental disorders and alcohol abuse. Between March 2003 and May 2011, 120,000 UK service personnel were deployed to Iraq, of whom 179 were killed. Operations overlapped with the campaign to defeat the Taliban in Afghanistan and this too proved a lengthy and challenging commitment, ending in December 2014 with 453 lives lost. A series of cohort studies published by KCMHR revealed that the incidence of probable PTSD was lower than that recorded for US forces. The British rates were 4 per cent overall and 7 per cent for frontline units, ${ }^{49}$ whereas studies of US troops found 13 per cent. ${ }^{50}$ Longer tours of duty undertaken by American forces together with shorter periods between deployments, service personnel of younger age and a higher proportion of reservists were cited as the causes. ${ }^{51}$ In July 1993, the MoD had set up the Medical Assessment Programme (MAP) to investigate the symptoms of any veteran who had served in the Gulf War. Data were gathered on the physical and mental health of self-referring, ex-service personnel. Two studies by Lee and colleagues based on 3,000 and 3,233 veterans, respectively, found no unique illness or unusual disease trends. ${ }^{52}$ Subsequent conflicts saw the MAP's role extended to include veterans of Bosnia, Iraq and Afghanistan. A study of 150 attendees with mental health problems, who believed these were caused by their operational service, was conducted Ian Palmer, a military psychiatrist. ${ }^{53}$ Only 15 per cent of the diagnoses were of PTSD, though 89 per cent of these cases were comorbid with depression (48 per cent) or alcohol abuse (40 per cent). 


\section{Women in the UK Armed Forces}

Until 1992, women who joined the armed forces had to serve in female-only units. With their abolition, women were integrated in all branches apart from those engaged in close combat. These changes corresponded with a progressive rise in the proportion of women in the UK armed forces. In 1990, women represented 6 per cent of regular forces, rising to 8 per cent by 2000 but had only achieved 11 per cent by April 2019 and are lower in the army than in the air force or navy. ${ }^{54}$ Not until December 2014 did the Women in Close Combat Review recommend ending the ban on women in the infantry and armoured corps. However, greater integration may have increased the risk of military sexual trauma (MST). Across the world, women in the armed forces report elevated rates of mental illness compared with their male counterparts. ${ }^{55}$ In part, this may reflect a greater willingness to disclose psychological illness but also the experience of a higher incidence of sexual assaults. ${ }^{56}$ To date, the MoD has not sanctioned independent study of MST on the grounds it is at a low level. ${ }^{57}$ In 2018, according to official statistics, service police conducted 153 investigations and 21 defendants were found guilty; the victims were mainly female (82.1 per cent) and the perpetrators overwhelmingly male. ${ }^{58}$ Yet the suggestion remains that cases are under-reported.

\section{Conclusion}

Public support for the individual soldier and media focus on the welfare of veterans raised the profile of military psychiatry during the 2000s. At the end of the decade, a new edition of the Armed Forces Covenant was informed by a review of mental health services conducted by Dr Andrew Murrison MP. ${ }^{59}$ Under the revised Covenant, veterans were granted priority access to NHS care for conditions associated with their service, subject to clinical need. The challenge of transition to civilian life was recognised and support in the form of 'training, education and appropriate healthcare referral' was recommended. ${ }^{60}$ However, in the years that were to follow, other clinical priorities arose as a result of continuing campaigns in Afghanistan and Iraq, notably mild traumatic brain injury and, when it was demonstrated that validated treatments for PTSD were less effective for military populations, a growing interest in moral injury. Hence, the psychological challenges of conflict continue to evolve and demand solutions.

\section{Key Summary Points}

- Because of the focus on Gulf War syndrome, the UK military were slow to investigate rates of PTSD in service and veteran populations.

- The 1998 Strategic Defence Review that led Britain into an interventionist foreign policy drew the armed forces into a series of campaigns that stretched their resources and created additional psychological stressors.

- Military psychiatry tends to advance during periods of conflict because of the attention given to psychological casualties. Although the number of health care professionals fell over the period 1960-2010 in step with reductions in the strength of the armed forces, research capacity grew driven by greater public scrutiny and the development of formal links with the King's Centre for Military Health Research.

- The 2002 Class Action at the Royal Courts of Justice into negligence in the detection and treatment of PTSD prompted the Ministry of Defence (MoD) to devote greater expenditure on research and the treatment of post-traumatic illnesses. 
- The integration of progressively increasing numbers of women into the UK armed forces may have led to an elevated risk of military sexual trauma (MST).

\section{Notes}

1. Ministry of Defence, UK Armed Forces Operational Deaths Post World War II. Bristol: Defence Statistics Health, 2015, p. 1.

2. C. McInnes, Labour's strategic defence review. International Affairs (1998) 74: 823-45.

3. The Strategic Defence Review, Cm 3999. London: The Stationery Office, 1998.

4. D. Edgerton, The Rise and Fall of the British Nation: A Twentieth-Century History. London: Allen Lane, 2018, pp. 514-17.

5. J. Price, The Falklands: Rate of British psychiatric casualties compared to recent American wars. Journal of the Royal Army Medical Corps (1984) 130: 109-13.

6. J. Price, The Falklands: Rate of British psychiatric casualties compared to recent American wars. Journal of the Royal Army Medical Corps (1984) 130: 109-13.

7. M. R. O'Connell, Stress-induced stress in a psychiatrist: A naval psychiatrist's personal view of the Falklands conflict. Stress Medicine (1986) 2: 307-14.

8. P. Abraham, Training for battleshock. Journal of the Royal Army Medical Corps (1982) 128: 18-27.

9. E. Jones and S. Ironside, Battle exhaustion: The dilemma of psychiatric casualties in Normandy, JuneAugust 1944. The Historical Journal (2010) 53: 109-28, 119.

10. L. Freedman, The Official History of the Falklands Campaign, Volume 2: War and Diplomacy. London: Routledge, 2005, pp. 628-9.

11. G. Jones and J. Lovett, Delayed psychiatric sequelae among Falklands War veterans. Journal of the Roy College of General Practice (1987) 37: 34-5.

12. L. S. O’Brien and S. Hughes, Symptoms of post-traumatic stress disorder in Falklands veterans five years after the conflict. British Journal of Psychiatry (1991) 159: 135-41.

13. R. Orner, T. Lynch and P. Seed, Long-term traumatic stress reactions in British Falklands War veterans. British Journal of Clinical Psychology (1993) 32: 457-9.

14. A. Rees, Suicide of Falkland veterans. Daily Mail, www.dailymail.co.uk/news/article-94492/SuicideFalklands-veterans.html.

15. Defence Analytical Services and Advice, A Study of Deaths amongst UK Armed Forces Personnel deployed to the 1982 Falklands Campaign: 1982-2012. Bristol: Ministry of Defence, 2013, p. 2.

16. E. Jones, Trans-generational transmission of traumatic memory and moral injury. Military Behavioral Health (2018) 6: 134-9.

17. M. R. O'Connell, Psychiatrist with the task force. In P. Pichot, P. Berner, R. Wolf and K. Thau, eds, Psychiatry: The State of the Art, Vol. 6. New York: Plenum Press, 1985, pp. 511-13.

18. E. Jones and S. Wessely, 'Forward psychiatry' in the military: Its origins and effectiveness. Journal of Traumatic Stress (2003) 16: 411-19.

19. R. Vinen, National Service, Conscription in Britain 1945-1963. London: Allen Lane, 2014, p. 256.

20. Hansard, Armed Forces, House of Commons debate, 14 December 1964, Vol. 404, Cols. 37-161, Frederick Mulley, Minister of Defence for the Army.

21. S. Noy, Division-based psychiatry in intensive war situations. Journal of the Royal Army Medical Corps (1982) 128: 105-16, 112-13.

22. P. Abraham, Training for battleshock. Journal of the Royal Army Medical Corps (1982) 128: 18-27. 
23. S. Noy, Division-based psychiatry in intensive war situations. Journal of the Royal Army Medical Corps (1982) 128: 105-16.

24. Abraham, Training for battleshock.

25. Ministry of Defence, Operational deaths post World War II, p. 1.

26. A. P. Finnegan, P. A. Cumming and M. E. Piper, Critical incident stress debriefing following the terrorist bombing at Army headquarters Northern Ireland. Journal of the Royal Army Medical Corps (1998) 144: 5-10.

27. D. Murphy, G. Hodgman, C. Carson et al., Mental health and functional impairment outcomes following a 6-week intensive treatment programme for UK military veterans with post-traumatic stress disorder (PTSD): A naturalistic study to explore dropout and health outcomes at follow-up. BMJ Open (2015) 5: e007051.

28. M. Gelder, D. Gath and R. Mayou. Oxford Textbook of Psychiatry. Oxford, Oxford University Press, 1986, p. 317.

29. L. S. O’Brien. Traumatic Events and Mental Health. Cambridge, Cambridge University Press, 1998, pp. 70-3.

30. G. Turnbull, Trauma, From Lockerbie to 7/7: How Trauma Affects Our Minds and How We Fight Back. London: Corgi, 2011, pp. 21-2.

31. J. T. Mitchell, When disaster strikes: The critical incident stress debriefing process. Journal of Emergency Medical Services (1983) 8: 36-9.

32. A. Dyregrov, Caring for helpers in disaster situations: Psychological debriefing. Disaster Management (1989) 2: $25-9$.

33. W. Busuttil, G. J. Turnbull, L. A. Neal et al., Incorporating psychological debriefing techniques within a brief group-psychotherapy program for the treatment of post-traumatic stress disorder. British Journal of Psychiatry (1995) 167: 495-502.

34. H. Lee and E. Jones, War and Health: Lessons from the Gulf War. Chichester: John Wiley, 2007.

35. A. B. Gillham and I. Robbins, Brief therapy in a battleshock recovery unit: Three case studies. Journal of the Royal Army Medical Corps (1993) 139: 58-60.

36. C. Unwin, N. Blatchley, W. Coker et al., Health of UK servicemen who served in the Persian Gulf War. Lancet (1999) 353: 169-78.

37. E. Jones, R. Hodgins Vermaas, H. McCartney et al., Post-combat syndromes from the Boer War to the Gulf: A cluster analysis of their nature and attribution, British Medical Journal (2002) 324: 321-4.

38. E. J. F. Hunt, S. Wessely, N. Jones, R. J. Rona and N. Greenberg. The mental health of the UK Armed Forces: Where facts meet fiction. European Journal of Psychotraumatology (2014); 5, https://doi.org/10.3402/ejpt .v5.23617.

39. N. Greenberg, A. Iversen, L. Hull, D. Bland and S. Wessely, Getting a peace of the action: Measures of posttraumatic stress in UK military peacemakers. Journal of the Royal Society of Medicine (2008) 101: 78-84.

40. R. J. Rona, M. Jones, C. French, R. Hooper and S. Wessely, Screening for physical and psychological illness in the British Armed Forces: I: The acceptability of the programme. Journal of Medical Screening (2004) 11: 148-53.

41. S. McManus, P. Bebbington, R. Jenkins and T. Brugha, eds, Mental Health and Wellbeing in England: Adult Psychiatric Morbidity Survey 2014. Leeds: NHS Digital, 2016, p. 114.

42. A. Iverson, A. Waterdrinker, N. T. Fear et al., Factors associated with heavy alcohol consumption in the UK armed forces: Data from a health survey of Gulf, Bosnia, and Era Veterans. Military Medicine (2007) 172: 956-61.

43. R. Jay and J. Glasson, The PTSD litigation. Journal of Personal Injury Law (2004) 2: 120-30.

44. T. McGeorge, J. Hacker Hughes and S. Wessely, The MOD PTSD decision: A psychiatric perspective. Occupational Health Review (2006) 122: 21-8.

45. E. B. Foa, B. O. Rothbaum, D. S. Riggs and T. B. Murdock, Treatment of posttraumatic stress disorder in rape victims: A comparison between cognitive-behavioral procedures and counselling. Journal of Consulting and Clinical Psychology (1991) 59: 715-23. 
46. T. M. Keane, J. A. Fairbank, J. M. Caddell and R. T. Zimering, Implosive (flooding) therapy reduces symptoms of PTSD in Vietnam combat veterans. Behaviour Therapy (1989) 20: 245-60.

47. J. I. Bisson and N. Jones, Taped imaginal exposure as a treatment for PTSD reactions. Journal of the Royal Army Medical Corps (1995) 14: 20-4.

48. M. M. Steenkamp, B. T. Litz, C. W. Hoge and C. R. Marmar, Psychotherapy for military related PTSD: A review of randomised controlled trials. JAMA (2015) 314: 489-500.

49. N. T. Fear, M. Jones, D. Murphy et al., What are the consequences of deployment to Iraq and Afghanistan on the mental health of the UK armed forces. Lancet (2010) 375: 1783-97.

50. C. W. Hoge, C. A. Castro, S. C. Messer et al., Combat duty in Iraq and Afghanistan, mental health problems. New England Journal of Medicine (2004) 351: 13-22.

51. J. Sundin, N. T. Fear, A. Iversen et al., Mental health outcomes in US and UK military personnel returning from Iraq. British Journal of Psychiatry (2014) 204: 200-7.

52. H. A. Lee, R. Gabriel, J. P. G. Bolton, A .J. Bale and M. Jackson, Health status and clinical diagnosis of 3,000 UK Gulf War veterans. Journal of the Royal Society of Medicine (2002) 95: 491-7; H. A. Lee, A. J. Bale and

R. Gabriel, Results and investigations on Gulf War veterans. Clinical Medicine (2005) 5: 166-72.

53. I. P. Palmer, UK extended Medical Assessment Programme: The first 150 individuals seen. Psychiatrist (2012) 36: $263-70$.

54. N. Dempsey, UK Defence Personnel Statistics. Briefing Paper CBP7930. London, House of Commons Library, 2019 , p. 6.

55. T. C. Smith, M. Zamorski, B. Smith et al., The physical and mental health of a large military cohort: Baseline functional health status of the millennium cohort. BMC Public Health (2007) 7: 340.

56. N. P. Mota, M. Medved, J. Wang et al., Stress and mental disorders in female military personnel: Comparisons between the sexes in a male dominated profession. Journal of Psychiatric Research (2012) 46: 159-67.

57. L. R. Godier-McBard and M. Fossey, Addressing the knowledge gap: Sexual violence and harassment in the UK armed forces. Journal of the Royal Army Medical Corps (2018) 164: 362-4.

58. M. Wigston, Report on Inappropriate Behaviours. London: Ministry of Defence, 2019, pp. 8-9.

59. A. Murrison, Fighting Fit: A Mental Health Plan for Servicemen and Veterans. London: Ministry of Defence, 2010.

60. Ministry of Defence, The Armed Forces Covenant. London: Ministry of Defence, 2011, p. 8. 